\title{
The Importance of the Governance Role in Achieving Stability and Sustainability in Family Business Companies Through Generations
}

\author{
Samir A. Abdelaziz \\ Correspondence: Assoc. Prof. Dr. Samir A. Abdelaziz, School of Business \& Economics, American International \\ Theism University - AITU, Florida, USA.
}

Received: June 21, 2021

doi:10.11114/bms.v7i3.5300

\author{
Accepted: July 5, 2021 \\ Online Published: July 19, 2021
}

URL: https://doi.org/10.11114/bms.v7i3.5300

\begin{abstract}
Family businesses have continued to draw researchers' attention due to their strategies while making sustainable decisions. Notably, these business models deserve more recognition in this discourse, considering that they contribute up to $70 \%$ of the global Domestic Product. This article focuses on some drivers to sustainable decisions revolving around three pillars: environmental, social, and economic. The author's aim in this context is to provide a statistical model that could be used to forecast revenue trends to establish if family businesses are poised for sustainability or not. The models essentially allow for an analysis of the relationship between family businesses' internal drivers with corresponding financial objectives.

However, these business models may fail to achieve their objectives if they do not embrace good governance, allowing them to react to challenges. Corporate governance is an essential framework that companies use to reconcile individual, community, business owners, and shareholders' interests in a dynamic global economy. Companies that align with the principles of good governance are more likely to remain sustainable, stable, and profitable. In retrospect, business enterprises that ignore the provisions of corporate governance risk facing uncertainties, most notably, dissolution and bankruptcy. The second, third, and subsequent generations fail to internalize and advance the founder's long-term organizational goals.
\end{abstract}

This study adds to the existing literature on economic sustainability of family businesses characterized by market value and higher revenue generation.

Keywords: Family businesses, corporate governance, sustainability, family dynamics, business dynamics, poor governance, board of directors

\section{Introduction}

\subsection{Background}

Family businesses have tremendous impacts on the global economy, considering that they are the most common ownership models. It is estimated that family businesses contribute up to $70 \%$ of the global Gross Domestic Product (GDP). The main characteristic of this form of business is that members of a single family are the largest stakeholders meaning that they have more say in the decision-making process. While these businesses have a significant economic value, they face governance challenges as they try to negotiate familial relationships, usually intertwined with business objectives. These challenges are more prevalent with the second and third generations, who may not internalize the initiators' objectives while setting the enterprises. Similarly, an overreliance on and recruitment of excess family members into leadership positions interferes with stability and sustainability since they may gain a sense of entitlement. This reality means managers, whether they are a part of the family or outsiders have to adopt good governance structures and processes. Good governance is critical since it paves the way for clarification of rights, relationships, and responsibilities, thus ensuring professional and responsible business management. 


\subsection{Research Objectives}

The objectives of this research is to:

a. Determine the extent to which good governance mitigates damages against family businesses.

b. Identify the extent to which professionalism enhances sustainability in companies and family businesses.

c. Highlight the roles that the top management plays in promoting good governance in corporates.

d. Establish the factors that force fail businesses to fail within the second and subsequent generations.

\subsection{Research Purpose}

The research aimed at establishing the importance of corporate governance in enhancing the sustainability of family businesses through generations.

\subsection{Research Questions}

a. Which factors lead to the failure of family businesses in the second and subsequent generations?

b. Which strategies could businesses adopt to separate between family and corporate interests?

c. What makes corporate governance a practical approach for mitigating damage to family businesses?

$\mathrm{d}$. What is the role of top management in ensuring the sustainability of general and family businesses?

\subsection{Research Gaps}

Corporate governance is considered a practical framework since it helps businesses design and implements strategic plans that enhance sustainability. However, as much as this form of governance improves corporate outcomes, family businesses are yet to embrace it. The existing literature focuses more on public limited and general companies, considering that they are more structured than typical business models. Conversely, most multinational companies began as family businesses, meaning that they deserve more attention.

\subsection{Author's Contribution}

The current research focused on the applicability of corporate governance in family businesses as they are more likely to dissipate following the death or decapitation of founders. A focus on family businesses in the Turkish context provided a framework for analyzing the relationship between corporate governance and sustainability. The findings from the research would be crucial as they provide the top management in these business models with a practical framework for balancing between corporate and family interests.

\section{Literature Review}

\subsection{The Extent to Which Governance can Avoid Damage to Family Businesses}

Family businesses are prone to numerous challenges, exacerbated by complex relationships that increase with multiple generations. Notably, these relationships can pave the way for commitment, love, and passion and, at the same time, drive intense rivalries, nepotism, and unhealthy power dynamics (Howorth \& Kemp, 2019). These dynamics mean a need for corporate governance, which would allow for the separation of control and ownership. Good governance plays a crucial role in ensuring the long-term success of family businesses because it helps the stakeholders negotiate business and family relationships. According to Parada et al. (2020), effective governance provides businesses with practical processes and procedures for managing competing interests and demands of the key stakeholders. However, for governance to cushion against damage to businesses, there is a need to focus on two distinct but interrelated areas of governance: corporate and family. Corporate governance refers to the structures that define relationships between a company's board of directors, shareholders, employees, and other stakeholders (Asensio-Lopez et al., 2019). On the other hand, family governance focuses on the processes and structures that families use to guide and organize their relationships with the enterprise (Gonzalez-Cruz, 2021). The incorporation of family and corporate governance ensures that the interests of all stakeholders and shareholders are balanced and taken into account.

Corporate governance is of particular interest in this discourse since it paves the way for family businesses to offer greater transparency to their principal stakeholders. The most practical approaches to achieving this transparency are board supervision, financial disclosure, auditing processes, and other institutional arrangements such as charity events (Sarbah \& Xiao, 2015). Traditionally, corporate governance is an approach associated with larger companies keen on streamlining the relationships between managers and shareholders. Similarly, larger companies rely on corporate governance to address conflicts of interest that arise and threaten the sustainability of an organization. However, the rise of family businesses that are more dynamic than other large organizations has facilitated the need to adopt corporate governance. Essentially, family businesses have pronounced separation of management and ownership; thus, they require a governance system to reduce the conflict of interests among the stakeholders. Ediriweera et al. (2015) note 
that businesses that adopt good governance structures and processes have better performance than poorly governed businesses. This assertion is very important, especially when focusing on family businesses under the management of second and third generations.

Family businesses face numerous challenges, especially in this era of increased globalization and growth. In particular, the expansion of family businesses paves the way for strained and complex relationships among managers, owners, and employees. Cirpan \& Alayoglu (2018) provide the example of Turkish businesses that face a challenge of balancing business and family dynamics, thus posing significant risks to sustainability and stability. Notably, the failure to separate business and family interests paves the way for poor management and conflicts, ultimately leading to bankruptcy (Cirpam \& Alayoglu, 2018). However, the adoption of good governance ensures that the stakeholders are accountable, considering it creates a centralized and organized entity. Similarly, governance is an effective tool that addresses multigenerational family businesses by ensuring that subsequent generations adhere to the founder's original objectives (Balderamma \& Jose, 2015). At the same time, good governance paves the way for the maintenance of key relationships and safeguarding the family's business health. A lack of good governance may increase the likelihood of infighting, which is occasioned by the desire to control, especially among second and subsequent generations. Overall, good governance allows for the restructuring of the existing procedures and processes to ensure that the interests of family and non-family stakeholders are preserved, thus guaranteeing sustainability and stability.

\subsubsection{Examples of Turkish Family Businesses with Good Governance}

Good governance is associated with sustainability, stability, productivity, and profitability, considering clear guidelines and functional structures that guide stakeholders. In retrospect, poor governance resulting in bad management practices is responsible for triggering scandals and financial crises that have been witnessed lately. The collapse of WorldCom and Enron corporations depicts the negative impacts of poor governance and the need for sound and practical approaches to governance. Essentially, companies with good governance structures can maximize the firm's value by aligning shareholders' interests. Turkey is one of the countries with many family businesses considering that they comprise $95 \%$ of all companies (East Agri). Koc Holding Company, a family business that began as a grocery store in 1917, is one of the most successful family businesses in this nation. The company has managed to differentiate itself from its competitors by achieving numerous breakthroughs, including being the only Turkish company on Fortune 500 Global list (Koc Holding, 2021). This company, which the third generation family members are managing, has adopted and adhered to corporate governance principles.

The Turkish government has made significant strides in supporting the growth of the family businesses scene, set in motion in the post-Ottoman empire. Previously, Greeks, Italians, and Jews had dominated family businesses, but with time, the government developed policies that helped Turkish-owned businesses to thrive. However, despite these efforts, Turkish family businesses have a short life expectancy that averages 25 years, meaning they are yet to adopt best corporate practices (East Agri, 2021). Similarly, only 30\% of all the family businesses survive the second generation, $12 \%$ survive the third generation, and only 3\% survive the fourth generation (East Agri, 2021). These diminishing statistics indicate a lack of a good governance structure, a reality that would negatively impact Turkish GDP and economic growth. This reality means a need for practical corporate governance that would pave the way for transferring unique capabilities across generations to enhance their competitive advantage (Kahveci \& Wolfs, 2019). The integration of corporate governance principles with family business culture provides a practical framework for handling challenges. Similarly, Turkish family businesses' adoption of corporate governance would create favorable circumstances that guarantee stability and sustainability in subsequent generations.

\subsection{Characteristics of Family Businesses with Good Corporate Governance}

Corporate governance is an effective framework that helps businesses reconcile various processes, stakeholders, and procedures, thus paving the way for sustainability and stability. However, companies must ensure that the approach to governance that they adopt demonstrates the requisite characteristics to achieve these objectives. The main characteristic of good governance is the direct poor indirect inclusion of all stakeholders in the decision-making processes. According to Alanazi (2019), most firms are headed by the board of directors, responsible for ensuring that all stakeholders are positioned to ensure that organizational goals and objectives are met satisfactorily. Notably, these top management level members succeed by providing employees with more autonomy, improving their engagement level. The other characteristic of good corporate governance is the insistence on transparency in all business processes and procedures. Family businesses are prone to fail, considering that subsequent generations may not have the same vision as their parents or grandparents who founded the enterprises. However, businesses that have adopted corporate governance provide detailed and timely disclosure of corporate information (Liu et al., 2016). This disclosure which is an aspect of business transparency, is crucial as it enables capital market investors to get reliable and sufficient information, thus facilitating informed economic decisions. Similarly, transparency reduces the likelihood of 
information asymmetry between enterprises and investors, compromising sustainability, competitiveness, stability, and profitability.

Family businesses that align with corporate governance principles and provisions have a higher likelihood of surviving beyond the first, second, third, and subsequent generations. This assertion is because good governance paves the way for a long-term strategic vision that incoming generations would achieve. Regrettably, most family businesses collapse when the founder (s) is incapacitated because the remaining family members cannot negotiate family and business dynamics. However, corporate governance becomes a framework for dealing with these dynamics by matching individuals with responsibilities and affirming the supremacy of the firm. Good corporate governance is responsible for ensuring that family businesses outperform other forms of enterprises when adopting economic changes and decision-making (Cioca et al., 2020). Notably, family businesses with good governance are in a position to leverage opportunities by taking advantage of family legacy, shareholder structure, and risk-aversion orientation (Alwadani \& Ndubisi, 2019). Furthermore, these businesses that have adopted good corporate governance are considered agile with an inclination to trustworthiness and innovation, thus putting them in a superior position.

Family businesses that account for a significant number of private companies are perceived to be sustainable business models and the backbone of the global economy. The reason these businesses are capable of outperforming non-family enterprises is the investment in good corporate governance. This governance framework is characterized by a quick reaction time which is the main driver for success for these enterprises. Essentially, family business managers are quick to think twice about investment choices by deploying detailed management analysis to determine the efficacy of alternatives (Cioca et al., 2020). Evidence indicates that family business governance and leadership approaches pave the way for creating enterprises with long-term investment capability, thus paving the way for sustainability and stability for subsequent generations. Similarly, good corporate governance gives family businesses more autonomy and control in decision-making, voting rights, and ownership of shares. This unique family influence plays a significant role in ensuring the continuity of the business across generations. There is a need to understand that a family's philosophy which emanates from its traditions, values, and beliefs, determines the extent to which corporate governance will impact its growth (Anglin et al., 2018). Nonetheless, there is a consensus that family businesses that have managed to separate family and business dynamics as espoused by corporate governance are sustainable and stable. Overall, good corporate governance helps family members view the business as supreme to their conflicting interests, perspectives, and pursuits, thus increasing the likelihood for success.

\subsection{Dangers of the Absence of Governance}

\subsubsection{Danger of the Absence of Governance in Companies}

Corporate governance is a crucial framework that enables companies to navigate the dynamic market considering that it aligns policies, procedures, and processes. Thus, a company that has poor governance risks poor economic outcomes, including bankruptcy. The rising incidences of corporate fraud in the US, as evidenced by the failure of Lehman Brothers and Enron, points to the consequences of bad governance. According to Dibra (2016), a strong governance framework is crucial since it paves the way for maintaining investor confidence, protecting stakeholders, and attracting foreign direct investment. In retrospect, poor corporate governance means that a business risks losing its investors and clients, which reduces its likelihood of being sustainable and stable. Corporate governance is heralded for its ability to allow for the separation of control and ownership in large stock corporations to reduce the likelihood of conflicting interests between managers and owners (Parada et al., 2020). The primary role of corporate governance is ensuring that enterprises fulfill the interests of corporate shareholders since they provide the requisite financial resources. In retrospect, poor governance interferes with this arrangement, considering that the management shifts their focus to meeting the interests of managers to the detriment of shareholders. Enron and Parmalat in Italy are examples of companies that failed their shareholders by engaging in financial frauds that were aimed at lying to shareholders that they were financially healthy. These examples indicate the negative impacts on companies that ignore the provisions entailed in the corporate governance framework.

Corporate governance provides companies with a framework that emphasizes the need for checks and balances, which supports organizational processes and procedures. As much as corporate governance cannot prevent unethical activities by the top management, it is a means of detecting such actions before it is too late. Thus, companies with poor governance are vulnerable to abuse, fraud, and other related issues, making them prone to bankruptcy and dissolution (Eccles \& Youmans, 2016). Similarly, a lack of checks and balances that corporate governance provides paves the way for poor performance, considering that managers are neither accountable nor transparent in financial reporting (Villiers $\&$ Dimes, 2021). The corporate governance framework addresses this challenge by advocating for mandatory reporting and disclosure of facial and non-financial information. However, there is a possibility that companies with poor governance will inflate profits and assets to gain the trust and confidence of investors, shareholders, and stakeholders. 
This misrepresentation of a company's financial health paves the way for the ultimate collapse of the enterprise and legal sanctions for the managers.

\subsubsection{Dangers of the Absence of Governance in Family Businesses}

Family businesses contribute to the global economy by creating employment opportunities and submitting significant amounts to local and national tax revenue. Businesses that have adopted good corporate governance fulfill this mandate considering that they are bound to operate for many generations. In retrospect, family businesses with poor governance are likely to cease operation when the founder (s) is incapacitated. Notably, the lack of a corporate governance structure paves the way for conflicts with every family member seeking entitlement to the business operations. Family businesses are usually motivated by non-economic goals, specifically preserving wealth and control over the firm (Ponomareva \& Ahlberg, 2016). These objectives create incongruence with non-family shareholders, especially if they feel that the family members deny them the chance to control the most crucial aspects of the business. Conversely, there is a consensus that boards constituted by a higher proportion of non-family directors who are independent of the management exercise more control and vigilance (Azizi et al. 2020). This aspect is, however, possible for family businesses that have adopted good governance principles and provisions. On the other hand, poorly governed businesses are characterized by never-ending conflicts, especially by the second and subsequent generations.

Good governance provides businesses with a framework to enact, implement, monitor, and evaluate policies, rules, and practices that outline how the board of directors oversees corporate activities. Similarly, it paves the way for a practical organizational structure used for defining relationships and processes. However, not all family businesses operate within these rules and frameworks, thus increasing the likelihood of failure occasioned by bankruptcy or scandals. In particular, most family members feel that they are entitled to positions of power even though they may not have the requisite skills and qualifications. This sense of entitlement interferes with organizational processes and procedures, considering that these individuals are not willing to listen to others' opinions. This entitlement is why some of the family boards are passive organizational bodies whose work is to rubber-stamp decisions, meaning they lack internal controls (Gonzalez-Bustos et al., 2020). The absence of internal control mechanisms translates to efficiency loss which then compromises the enterprise's ability to maximize shareholder value. At the same time, family businesses with poor governance structures are more likely to frustrate non-family members considering that they are keen on guarding their wealth (Ponomareva \& Ahlberg, 2016). This close supervision denies these managers the autonomy they require to accomplish their duties, thus paving the way for high turnover rates. Consequently, shareholders and stakeholders lose their confidence in the business, thus paving the way for the ultimate dissolution and collapse.

\subsection{Professionalism in Corporate Governance}

The dynamic global market challenges businesses as they try to balance changing demands, ethical integrity, and accountability. This reality means that the responsibility and accountability of business enterprises are constantly subjected to scrutiny. These overt failures indicate that there is a possibility that the existing corporate governance frameworks and structures have failed. Nevertheless, businesses could overcome these challenges if they design corporate governance approaches that depict adherence to high levels of professionalism (Salavtore \& Numerato, 2017). Notably, most companies that realize this fact are keen on fulfilling their environmental and social responsibilities through efficient use of the available resources. Corporate governance, which is focused more on balancing between communal and individuals' social and economic goals, paves the way for professionalism (Macheridis \& Paulsson, 2019). Essentially, professionalism in corporate governance entails providing the stakeholders with performance measures and incentives that would enhance business success. Similarly, professionalism emphasizes that all business processes and procedures should demonstrate high levels of accountability and transparency to pave the way for an equitable distribution of wealth (Huberts 2018). These principles, which are usually ingrained in corporate governance, highlight the need for stakeholders to fulfill their obligations for the greater good.

Family businesses are prone to dissolution to failure, especially when they are managed by subsequent generations who may not have the same passion and commitment as founders. Despite this reality, these businesses can thrive and gain a competitive advantage over the non-family business if they adopt corporate governance principles in all procedures and processes. Corporate governance provides businesses with a framework for engaging in more proactive and positive roles that enhance social equity and stability (Kahveci \& Wolfs, 2019). This aspect of corporate governance emphasizes professionalism as a means for businesses to achieve higher-level goals. In retrospect, businesses that fail to adhere to the provisions of corporate governance risk engaging in unethical practices, which occasions their failure (Huberts, 2018). The collapse of major corporations, most specifically Enron and Lehman Brothers, indicates a lack of professionalism. However, this need not be the case for other businesses, considering that corporate governance allows for reconciling individual and organizational interests, thus paving the way for sustainability and stability (Liu et al., 2016). Businesses that model their operations and procedures against corporate governance principles, most notably 
integrity, transparency, and professionalism early in their life cycle, will succeed. Overall, professionalism should be considered a significant business pillar that emphasizes the need to adhere to best business practices and procedures.

\subsection{Top Management Teams Views on Governance}

Companies are aware that an investment in good leadership increases the likelihood of achieving organizational stability and sustainability. Leaders are keen on aligning and adhering to business principles that emphasize that it is crucial to match individuals with tasks and processes. The top management, which includes the board of directors and mid and upper-level managers, believes that governance is a tool that paves sustainability. Similarly, governance outlines strengthen and spread organizational culture by highlighting expectations, behaviors, and attitudes (Mugwang'a et al., 2018). Thus, for top managers who possess distinct perceptions that result from learning, past know-how, and individual morals, governance is a framework for evaluating circumstances that relate to organizational performance. Notably, top managers who adhere to the principles of good governance promote flexibility, cohesion, open-mindedness to enhance the success of strategic organizational objectives. Furthermore, top managers embrace corporate growth, which entails separating and diverting control and ownership of governance structures (Gonzalez-Bustos et al., 2020). This role is pivotal, considering that it allows for the alignment of managers' and owners' economic interests as espoused in corporate governance principles.

The board of directors is a fundamental aspect of corporate governance discourse, considering that it is the custodian of shareholders' interests. There is a consensus that if these boards effectively dispense their mandate, companies must adopt governance structures that allow the nomination of non-family directors (Parada et al., 2020). Similarly, family businesses must be willing to institute special board committees to separate the roles undertaken by the chief executive officer and the chairman of the board. The inclusion of non-family directors is a practical solution since they would bring in new perspectives that would help in resolving perennial challenges (Mugwang'a et al., 2018). On the other hand, the separation of CEOs and board chairman roles will allow executives to monitor executives to improve corporate performance. Apart from performance, top managers should view governance as a tool for ensuring that an organization addresses social and environmental interests through corporate social responsibility. Boards ought to outline their approach to CSR and, at the same time, create incentives that would go a long way in eliciting participation (Gonzalez-Bustos et al., 2020). Overall, governance increases the likelihood for organization success since it ensures that top managers understand the needs of their stakeholders and from here adopt practical strategies for addressing them.

\section{Methodology}

\subsection{The Model}

Following a thorough review of literature, the researcher developed several research questions related to the sustainability of family businesses across generations:

RQ1: Which factors lead to the failure of family businesses in the second and subsequent generations?

RQ2: Which strategies could businesses adopt to separate between family and corporate interests?

RQ3: What makes corporate governance a practical approach for mitigating damage to family businesses?

RQ4: What is the role of top management in ensuring the sustainability of general and family businesses?

The researcher selected the main non-financial drivers of sustainability in family businesses that correspond with financial objectives to answer these questions, as evidenced in Table 1.

Table 1. Family Drivers Financial objectives

\begin{tabular}{lr}
\hline Open communication and harmony in the family & Long-term business performance \\
\hline Family influence and control & Percentage of voting rights \\
\hline Sustainability across generations & Preservation of capital \\
\hline Type of family culture & Percentage of business shares \\
\hline Ability to innovate & Reinvestment of profit \\
\hline Discipline and expertise & Business environment awareness \\
\hline Source: Author & \\
Having analyzed the drivers for sustainability in family businesses, the researcher used quantitative and qualitative \\
research in two stages. The first one involved analyzing reports on top-ranked family businesses to identify financial \\
drivers, notably acquisition, corporate governance, and preoccupation with value creation. The second stage focused on \\
the employees, considering that their experience and expertise enhance organizational performance. Notably, a family \\
company with well-educated and experienced employees is poised to have additional projects that would raise its
\end{tabular}


revenue stream and achieve sustainability. Employees thus become a crucial asset as they are cost-efficient and are connected with the family business growing revenue.

\subsection{Sample}

According to the Family Capital report, the study analyzed the top 100 family businesses in the world in the 2017-2019 world. These businesses were chosen to establish their economic projection and similarities in terms of sustainability decisions and revenues over the years. Furthermore, the researcher analyzed surveys from consulting firms that conduct annual research on the sustainability of family businesses. Notably, the researcher focused on the KPMG's survey on family businesses in the European Union Bloc, Global Family

Business Survey 2017/2018 by PricewaterhouseCoopers and "Connect for Impact," a report by Deloitte. The surveys contained crucial statistics on family businesses included in this equation to enhance an understanding of sustainability across generations. The researcher chose this period to forecast future revenue by focusing on family shareholding percentage, market capitalization, turnover, number of employees, and market value.

\subsection{AProcedure}

The researcher considered and analyzed family businesses with skilled experts, adequate organization structure, and experienced managers. Focusing on these aspects was to ensure that the included companies would generate maximum profits that would enhance their sustainability. This article focuses on the benefits and revenues that these companies gain before determining the cost of goods sold to measure performance and sustainability. It is important to note that these characteristics are related, considering that they affect all the financial processes of any family business entity. As such, the researcher grouped and computed these characteristics into financial and non-financial. The researcher computed non-financial values by considering the percentage of family shareholding since more shares translate to more voting rights, which in turn influence strategic business decisions. Next, the researcher calculated financial values by focusing on market value, number of employees, and business size, considering that they show a company's real potential. This computation was to establish the relationship between strategic governance, revenue generation, and sustainability. Finally, comparing the previous year's financial data allowed the researcher to calculate the change in revenue to determine how well these family businesses had evolved.

\subsection{Measures}

This research intended to design a model that could forecast sustainability trends in the future by analyzing data on revenue from previous periods. The study relied on a multiple regression model based on four independent variables to determine future revenue values. The researcher began by exploring the relationship between the variables before building and interpreting the regression output. Essentially, the author assumed that these revenues would depend on the following current year's variables:
a. Percentage of family shares
b. The actual number of employees
c. Market value.
d. Market capitalization.
e. Current year's revenue

The author then adopted an additive multiple regression for exploring the impact of these variables on sustainability, thus creating the following formula

\section{Revenue Generation $=$ Family shareholding + Employees + Market value + Market capitalization + Turnover}

Thus, future revenue that correlates with family businesses' sustainability is the independent variable that can be measured using financial and non-financial indicators. Apart from the financial reports, the researcher highlighted the need for companies to write non-financial reports that provide a comprehensive business image.

\subsection{Data and Analysis}

The researcher runs a summary of statistics to examine the five dependent variables that determine family businesses sustainability. Notably, each of the variables included in this analysis contains 70 observations with no missing values. Table 2 depicts the median, mean, range of variables, and standard deviation, illustrating that revenues in 2018 varied from $\$ 17,235$ million to 427,340 million while the median was $\$ 45,453$ million. Family shareholding, the other independent variable, varied from $32.6 \%$ to $98 \%$, with a mean of $54.6 \%$ and a median of $49.7 \%$. The number of employees in the companies considered in this study ranged from 7865 to 2.13 million, while the median was 123,143 . The market value ranges from 746.6 to 654,143 , with the average being 90,122.81. On the other hand, market capitalization ranged from $\$ 3234$ million to $\$ 456,267$ million, with a mean value of $\$ 74,324$ and a median value of $\$ 38,239$ million. Finally, the turnover average is 5.1 with a minimum and maximum value of -17.56 to 39.3 . The 
analysis establishes a skewness to the right since the media values are lower than mean values. Nonetheless, the skewness does not contradict the normality assumption considering that the study focused on large sample size.

Table 2. Summary Statistics

\begin{tabular}{lllllll}
\hline & $\begin{array}{l}2018 \\
\text { revenues } \\
\text { millions \$ }\end{array}$ & $\begin{array}{l}\text { in } \\
\text { Shareholding } \\
2017\end{array}$ & $\begin{array}{l}\text { Number of } \\
\text { Employees } \\
2017\end{array}$ & $\begin{array}{l}\text { Market } \\
\text { Value 2017 }\end{array}$ & $\begin{array}{l}\text { Market Capitalization } \\
\text { In millions \$ as of 31 } \\
\text { December 2017 }\end{array}$ & $\begin{array}{l}\text { Turnover } \\
2017\end{array}$ \\
\hline Mean & $75,345.30$ & 54.60967 & $213,342.9$ & $90,122.81$ & $74,324.50$ & 5.184632 \\
Median & $45,453.52$ & 49.70000 & $123,143.2$ & $23,456.00$ & $38,239.50$ & 3.700000 \\
Minimum & $17,235.9$ & 32.60000 & 7865.000 & 746.6000 & 3234.500 & -17.56 \\
Maximum & $427,340.12$ & 98.00000 & $2,123,000$ & $654,143.0$ & $456,267.6$ & 39.300000 \\
$\begin{array}{l}\text { Standard } \\
\text { deviation }\end{array}$ & $94,234.34$ & 17.88765 & $287,345.4$ & $149,324.2$ & $97,345.02$ & 10.34528 \\
\hline
\end{tabular}

Source: Author

\section{Discussion}

Market value and the number of employees are the two variables that significantly impact revenue generation and sustainability in family businesses. This finding indicates that an experienced management team and well-educated employees can influence the growth of a company. Notably, a family business would require reliable employees who can manage a rise in demand through successful innovations. Similarly, sustainability in family businesses depends on the market value, which positively impacts revenue forecasts. Essentially, private equity companies or investors would be interested in family businesses with a high market value that depict growing revenues. However, the analysis has established that the other variables in the empirical study do not significantly impact family businesses' sustainability.

\section{Conclusion}

The business environment is dynamic, meaning companies have to constantly adopt new strategies to retain their competitive advantage and increase sustainability. Family businesses, in particular, are in a peculiar position first as the most common business model and second as being more prone to scandals, dissolution, and bankruptcy. Notably, most family businesses do not survive to the second, third, and subsequent generations because of infighting and poor governance. There is a consensus that the failure to internalize and comprehend the founder(s) initial objective of establishing a particular business contributes to its downfall. Similarly, family members out of entitlement believe that they do not require a formal structure to ensure the continuity of a business. These perspectives create significant loopholes, which, if not addressed, increase the likelihood of a lack of internal control mechanisms and failure. Nonetheless, family businesses can still survive these challenges if the top managers who should not necessarily be family members adhere to corporate governance principles. Essentially, corporate governance provides companies with a framework that regulates behaviors to increase the likelihood for transparency, accountability, collaboration, and mutual respect. Ultimately, good governance helps family businesses internalize and adopt best practices that ensure companies' sustainability and preservation of wealth through subsequent generations.

\section{References}

Alanazi, A. S. (2019). Corporate governance and the characteristics of the board of directors: Evidence from an emerging market. Corporate Board: Role, Duties and Composition, 15(1), 17-24. https://doi.org/10.22495/cbv15i1art2

Alwadani, R., \& Ndubisi, N. O. (2019). Sustainable family business: The role of stakeholder involvement, mindful organizing, and contingent human factors. International Journal of Manpower, 41(7), 945-965. https://doi.org/10.1108/IJM-08-2019-0359

Anglin, A. H., Reid, S. W., Short, J. C., Zachary, M. A., \& Rutherford, M. W. (2017). An archival approach to measuring family influence: An organizational identity perspective. Family Business Review, 30(5), 19-36. https://doi.org/10.1177/0894486516669254

Asensio-Lopez, D., Cabeza-Garcia, L., \& Gonzalez-Alvarez, N. (2019). Corporate governance and innovation: A theoretical review. European Journal of Management and Business Economics, 28(3), 266-284. https://doi.org/10.1108/EJMBE-05-2018-0056

Azizi, M., Bidgoli, S. M., \& Taheri, A. (2021). The effect of ownership and management structure on family business performance. Cogent Business \& Management, 8(1), 11-29. https://doi.org/10.1080/23311975.2021.1872888

Balderamma, P., \& Jose, M. (2015). Developing governance structures in family firms: From adoption to institutionalization (Doctoral dissertation). Available from DiVa Portal: JIBS Dissertation Series No. 103. 
Cioca, A., Wehbe, K., Popescu, D., \& Popescu, C. (2020). The main drivers for sustainable decisions in a family business that impact the company's performance. Sustainability, 12(20), 59-86. https://doi.org/10.3390/su12208659

Cirpan, H., \& Alayoglu, N. (2018). Challenges of Turkish family businesses related to effective management strategies. In: Aysan A., Babacan M., Gur N., Karahan H. (eds) Turkish economy, 385-409. Palgrave Macmillan. https://doi.org/10.1007/978-3-319-70380-0_17

Dibra, R. (2016). Corporate governance failure: The case of Enron and Parmalat. European Scientific Journal, 12(16), 283-290. https://doi.org/10.19044/esj.2016.v12n16p283

East Agri. (2021). Corporate governance in Turkish family-owned businesses. Retrieved from $\mathrm{http}: / /$ www.eastagri.org/projectcorner/index.php?id=148

Eccles, R., \& Youmans, T. (2016). Materiality in corporate governance: The statement of significant audiences and materiality. Journal of Applied Corporate Finance, 28(2), 39-46. https://doi.org/10.2139/ssrn.2654199

Ediriweera, A., Armastrong, A., \& Heenetigala, K. (2015). Governance in a family business: A literature review. Journal of Law and Governance, 10(2), 36-46. https://doi.org/10.15209/jbsge.v10i2.854

Gonzales-Bustos, J. P., Hernandez-Lara, A. B., \& Li, X. (2020). Board effects on innovation in family and non-family business. Heliyon, 6(9), 49-80. https://doi.org/10.1016/j.heliyon.2020.e04980

Gonzalez-Cruz, T., Almendros, J. A., \& Puig-Denia, A. (2021). Family governance systems: The complementary role of constitutions and councils. Economic Research, 12(3), 45-62. https://doi.org/10.1080/1331677X.2020.1867603

Howorth, C., \& Kemp, M. (2019). Governance in family businesses: Evidence and implications. IFB Research Foundation.

Retrieved

from

https://www.ifb.org.uk/media/4133/governance-in-family-businesses-evidence-and-implications_web.pdf

Huberts, L. W. (2018). Integrity: What it is and why it is important. Public Integrity, 20(3), 18-32. https://doi.org/10.1080/10999922.2018.1477404

Kahveci, E., \& Wolfs, B. (2019). Family business, firm efficiency, and corporate governance relation: the case of corporate governance index firms in Turkey. Academy of Strategic Management Journal, 18(1), 1-12.

Koc Holding. (2021). About. Retrieved from https://www.koc.com.tr/about-us

Liu, Y., Valenti, A., \& Chen, Y. (2016). Corporate governance and information transparency in Taiwan's public firms: The moderating effect of family ownership. Journal of Management \& Organization, 22(5), 662-679. https://doi.org/10.1017/jmo.2015.56

Macheridis, N., \& Paulsson, A. (2019) Professionalism between profession and governance: How university teachers' professionalism shapes coordination. Studies in Higher Education, 44(3), 470-485. https://doi.org/10.1080/03075079.2017.1378633

Parada, M. J., Gimeno, A., Samara, G., \& Saris, W. (2020). The adoption of governance mechanisms in family businesses: An institutional lens. Journal of Family Business Management, 10(2), 33-47. https://doi.org/10.1108/JFBM-07-2019-0054

Ponomareva, Y., \& Ahlberg, J. (2016). Bad governance of family firms: The adoption of good governance on the board of directors in family firms. Theories and Politics in Organizations, 16(1), 53-77.

Salvatore, D., \& Numerato, D. (2017) Governance and professionalism. In: Farazmand A. (eds) Global encyclopedia of public administration, public policy, and governance, 46-62. Springer. https://doi.org/10.1007/978-3-319-31816-5_3340-1

Sarbah, A., \& Xiao, W. (2015). Good corporate governance structures: a must for family businesses. Open Journal of Business and Management, 3, 40-57. https://doi.org/10.4236/ojbm.2015.31005

Villiers, C., \& Dimes, R. (2021). Determinants, mechanisms, and consequences of corporate governance reporting: a research framework. Journal of Management and Governance, 25, 7-26. https://doi.org/10.1007/s10997-020-09530-0

\section{Copyrights}

Copyright for this article is retained by the author(s), with first publication rights granted to the journal.

This is an open-access article distributed under the terms and conditions of the Creative Commons Attribution license which permits unrestricted use, distribution, and reproduction in any medium, provided the original work is properly cited. 